Mirostawa DEUGOSZ, Ewa WORNIAŁŁO

\title{
VARIABILITY OF VENDACE (COREGONUS ALBULA L.) GONADS IN THE ANNUAL CYCLE, IN THREE LAKES OF MAZURIAN LAKELAND
}

\section{ZMIENNOSĆ GONAD SIELAWY (COREGONUS ALBULA L.) W CYKLU ROCZNYM,} Z TRZECH JEZIOR POJEZIERZA MAZURSKIEGO*

\author{
Department of Basic Fishery \\ Sciences - Olsztyn
}

In the lakes under study vendace was characterized by different duration of particular stages of male and female gonad development, and different periods of spawning.

\section{INTRODUCTION}

Coregonid fishes, in this vendace (Coregonus albula L.) are quite popular in the waters of North Poland, Their commercial value is very high, hence they constitute a subject of continuous interest of the fisheries. Vendace spawns in autumn. Żuromska (1982) found that in lakes Pluszne and Maróz peak of vendace spawning started during homothermy, and ended after winter thermal stratification had established, frequently already under the ice cover. Bernatowicz (1963) observed that in the lakes of Mamry complex vendace commenced spawning at water temperature of $7.7-6.7^{\circ} \mathrm{C}$. However, if the temperatures

\footnotetext{
* The work represents part of complex studies carried out by the Inland Fisheries Institute in Olsztyn, within the frames of a govermental projest PR -4 .
} 
dropped rapidly in course of the spawning, its intensity increased, so that it was over in a rather short time.

Natural spawning of vendace and egg incubation period upon the spawning grounds are critical for this species. Consequently, this period is of considerable interest for the ichthyologists.

Histological observations on the annual cycle of vendace gonad development are not too numerous. In Poland, microscopic changes taking place in vendace gonads were observed by Backiel (1952) and Zawisza and Backiel (1970). These authors worked out a scale of gonad development, described histological changes in ovaries and testes, and related them to macroscopically noticeable features. Sinjavičjus and Sinjavið̌enje (1975) noted that in natural Lithuanian waters, from end of October till and of November, resorbtion of the oocytes was frequently observed in case of the oocytes which had already attained final size. Kužmin and Čubatova (1975) observed resorbtion of egg cells during the whole vitellogenesis in whitefish. These authors suggested that the observed phenomenon liquidated more developed oocytes, and led into homogeneity of the development of other cells. Backiel (1952) observed in vendace considerable differentiation of the spawning period, and concluded that this resulted from significant individual variability of maturation in vendace stocks. This author suggested that prolonged resorbtion of the spermatozoa and oocytes may disturb normal course of the metabolism.

Studies by Żuromska (1982a, b) and Wilkońska and Żuromska (1981) revealed considerable differences ketween vendace populations in particular Mazurian lakes. In view of this, histological observations were undertaken on gonads of this species. Their objective was to determine whether these inter-population differences can affect duration of particular stages of oocyte development in an annual cycle.

\section{MATERIALS AND METHODS}

Materials for histological studies on vendace gonads (both sexes) were collected from June 1982 till March 1983. Three lakes of Mazurian Lakeland were selected (Isąg, Narie, Lutry), differing as regards their limnology, and especially morphometry. Lake Isąg is situated north-west of Olsztyn. Its area is 395.7 ha, maximal depth $-54.5 \mathrm{~m}$, average depth $-14.2 \mathrm{~m}$. Lake Narie is situated north-east of Olsztyn. Its area is 1240.1 ha, maximal depth $-43.8 \mathrm{~m}$, average depth $-10.0 \mathrm{~m}$. Lake Lutry lies east of Olsztyn. Area - 691.1 ha, maximal depth - $20.7 \mathrm{~m}$, average depth - $7.2 \mathrm{~m}$ (Operat 1964, 1965, 1968). It was not possible to obtain water temperatures for the period under study.

The following measurements were made for each sampled fish: body length (lc), body weight (w), gonad weight (Og). Gonado-somatic incex (GSI) was also calculated. Fish age was determined from scales (Tab. 1, 2, 3, 4). Samples collected for histological studies were preserved in buffered formalin and immersed in paraffin. Scraps $6 \mu$ thick were stained with hematoxylin with yellow eosin. Developmental stages of the ovaries were 
defined according to the scale by Sakun and Buckaja (1968). Annual cycle of gonad development was divided into stages $\mathbb{I I}-\mathbb{V} \mathbb{I}$.

In case of females, stages II-III embraced a period of slow oocyte growth, stages $\mathbb{I V}-\mathbb{V}$ - period of intensive growt. Resting stage after spawning was defined as VI-III.

In case of males, stages $\mathbb{I}-\mathbb{I V}$ embraced a period of spermiogenesis, stage $V$ spawning period, and stage $V \mathbb{I}$ - resting period after spawning.

As regards the reproductive cells in the previtellogenetic period (II stage of ovary development), distinction was made between oocytes with nucleus shifted toward the cell wall $\left(\mathbb{I}_{2}\right)$, and cells with nuclei in central position ( $\left.\mathbb{I I}_{1}\right)$. Oocyte diameter was measured in the preserved material. Histological pictures were taken by Jerzy Waluga, M.Sc. (Phot. 1-12).

\section{OWN STUDIES}

\section{Lake Lutry}

First samples of vendace gonads were collected in August 1982. At this time the ovaries contained oocytes in which the vitellogenesis had commenced (III stage of

Table 1

Characteristics of vendace material from Lake Lutry, with consideration given to body length (lc), body weight (w), index of maturity (GSI) and fish age

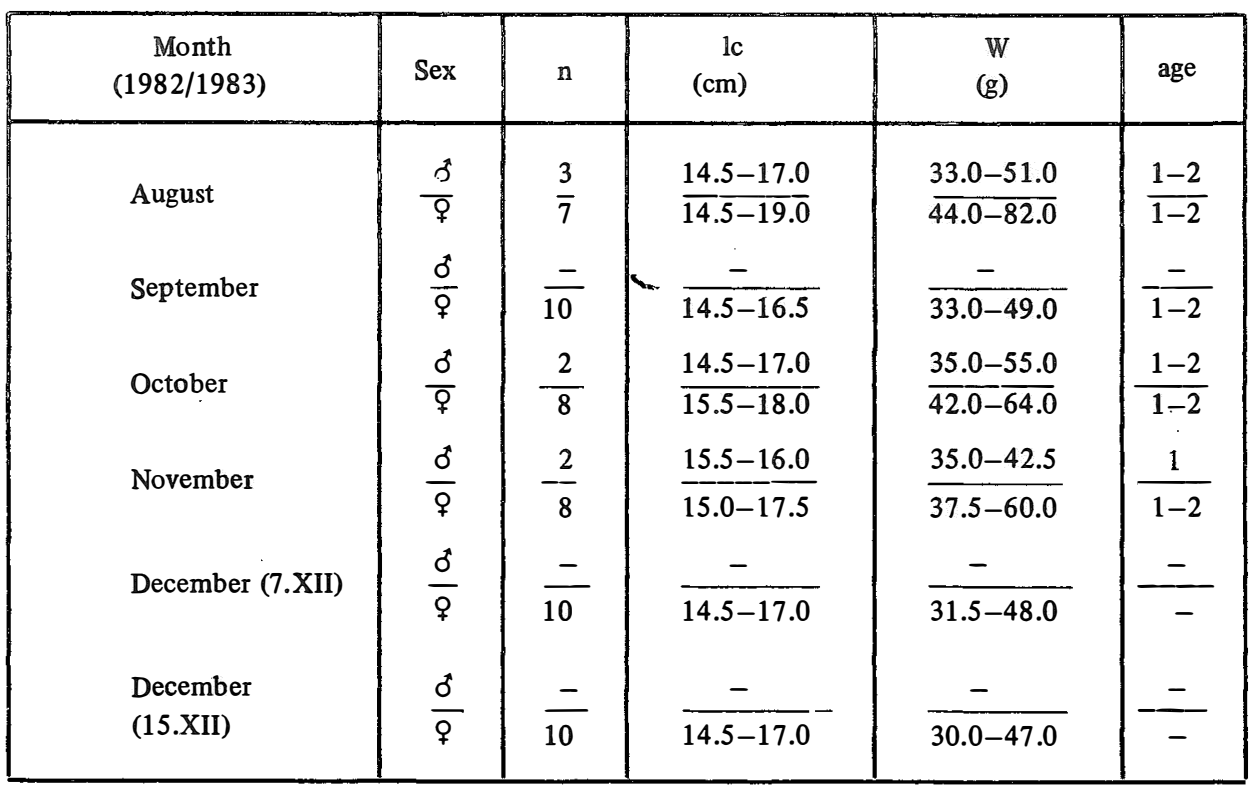




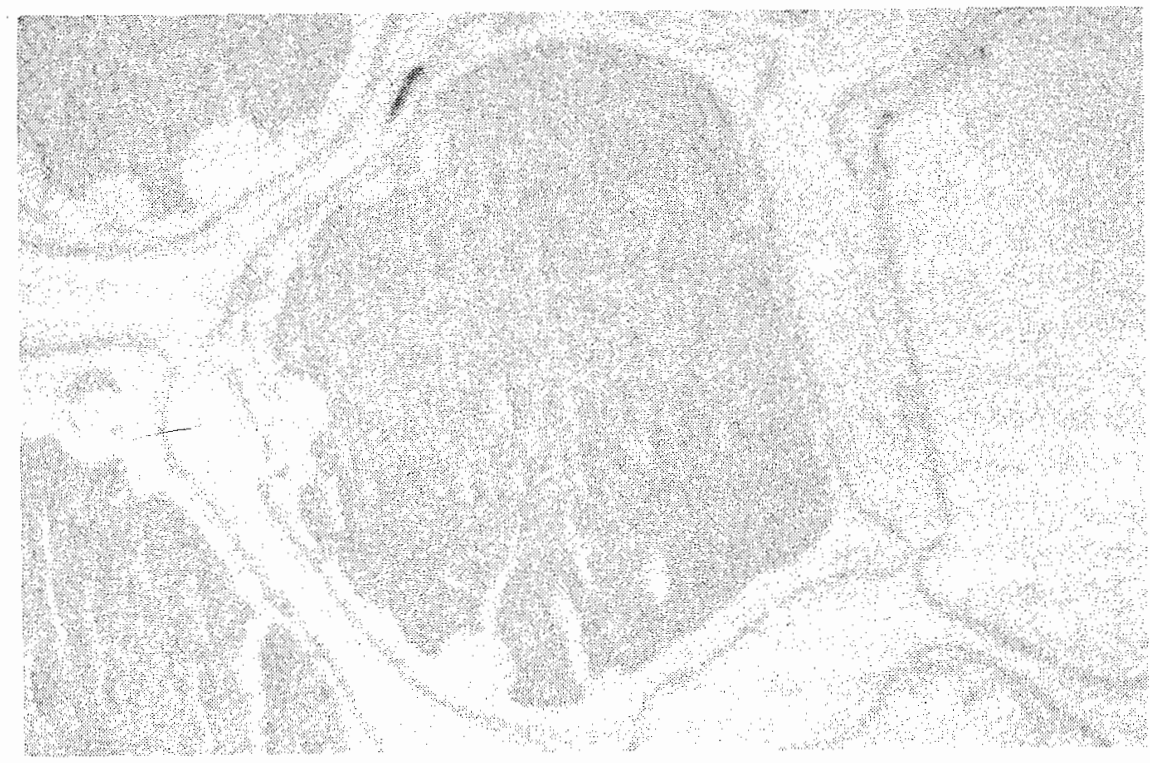

Fig. 1. November. Oocytes in the V stage of development. GSI 29.92\%. Lake Isag. (magn. 50x)

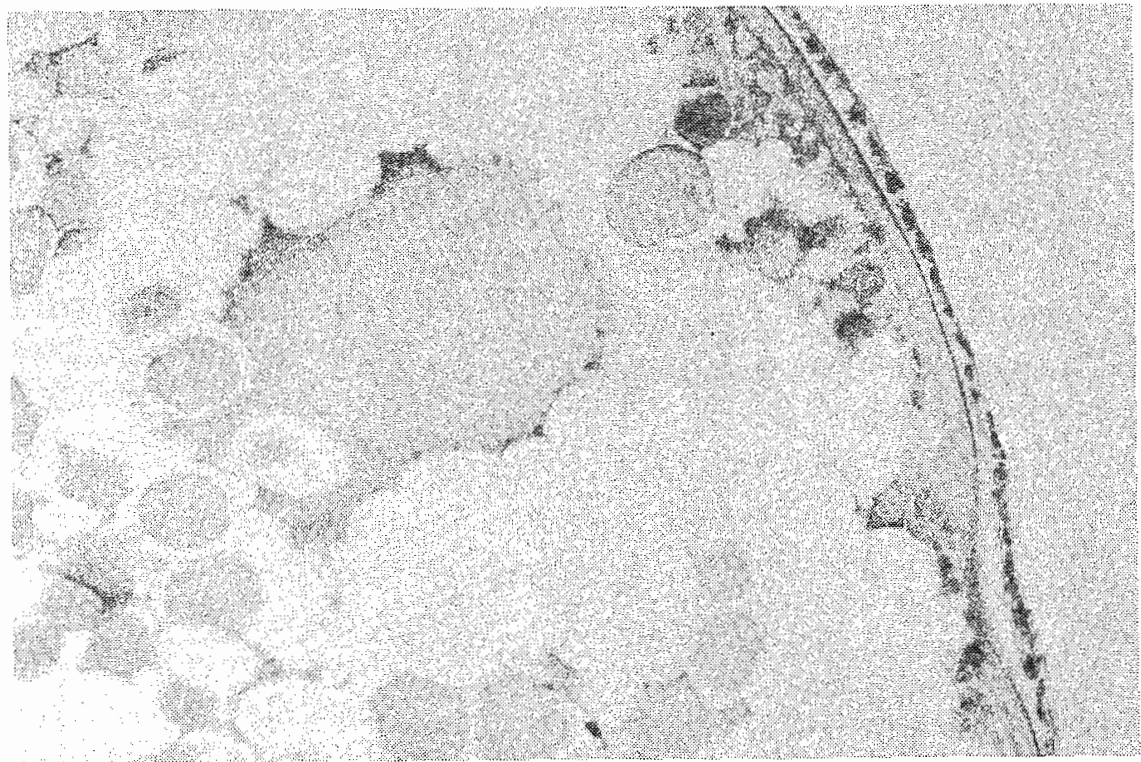

Fig. 2. December. Oocytes in the IV-V stage of development. GSI 20.98\%. Lake Lutry. (magn. 200x) 
maturity), vacuolized oocytes (III stage of maturity), and cells in the II stage. Maturation index ranged from 2.44 to $4.58 \%$ (Tab. 1, 4). Such a picture of the ovaries was observed untill November. In November samples, part of the females had ovaries in the IV and IIIa stage of maturity. Diameter of the oocytes varied between 640.0 and $1388.4 \mu \mathrm{m}$. Gonado-somatic index amounted to 13.33-18.42\%. However, in some fishes the gonads contained the oocytes in the IIIa stage. At the same time cells with single vacuoles in the cytoplasm appeared. Their size ranged between 217.6 and $256.0 \mu \mathrm{m}$. In samples collected on 7 and 15 December 1982, some females had ovaries in the IV/V stage of development (Fig. 2), or in the VI-III stage. Diameter of mature cells ranged from 1075.2 to $1600 \mu \mathrm{m}$, and GSI varied between 0.25 and $26.5 \%$. After spawning (VI-III stage) empty follicular membranes were observed in the gonads, as also single cells with one ring of vacuoles and oocytes in the III stage of maturity.

Male gonads in August were highly differentiated. Part of the males had spermatozoa in the light of ampulas, whereas in other the cyst walls were very broad. The latter gonads were in the II stage of maturity. Gonado-somatic index amounted to $0.98-1.51 \%$. In October the spermiogenesis was more intensive. Amount of spermatoids in the ampules increased noticeably, while the maturation index reached $1.42-1.80 \%$ (III-IV stage).

By the end of November thin-wall ampules were filled with mature spermatozoa. Index of maturity amounted to $2.35 \%$. At the begining of December males were ready for spawning.

\section{Lake Narie}

In June vendace ovaries were in the III or early III stage of development. In the latter case the oocytes contained single yolk granules around the cell nucleus. Oocytes in the IIIa, III and II $_{1,2}$ stage of development were observed in the histological picture. In July the cells were in stage IIIa and contained more nutritive substances. At that time the oocytes (which were vacuolized previously) commenced vitellogenesis. No vacuolized cells were noticed any more.

Females collected in October had the ovaries in the IV stage of maturity. Amoeboidal nucleus shifted toward the animal pole, and bigger granules of fat and yolk filled the oocyte interior. All the time egg diameter remained quite asynchronical. In November size of the oocytes varied from 678.4 to $1587.2 \mu \mathrm{m}$. Accumulation of tropic substances lasted untill November. Since June till November oocytes in the previtellogenetic stage were observed in the histological picture of the ovaries. However, cells with the smallest diameter $\left(38.4 \mu \mathrm{m}-\mathbb{I}_{2}\right.$ stage) were most numerous in December, March, July and August. At that time the gonad-somatic index reached the highest value of $24.3 \%$ (Tab. 2, 4).

Analysis of two samples collected in December revealed that vendace females did not commence spawning at the same time. Part of the females had the ovaries in the IV or V stage of development, whereas the other had already reached the VI-III stage (Tab. 2) 4)). 


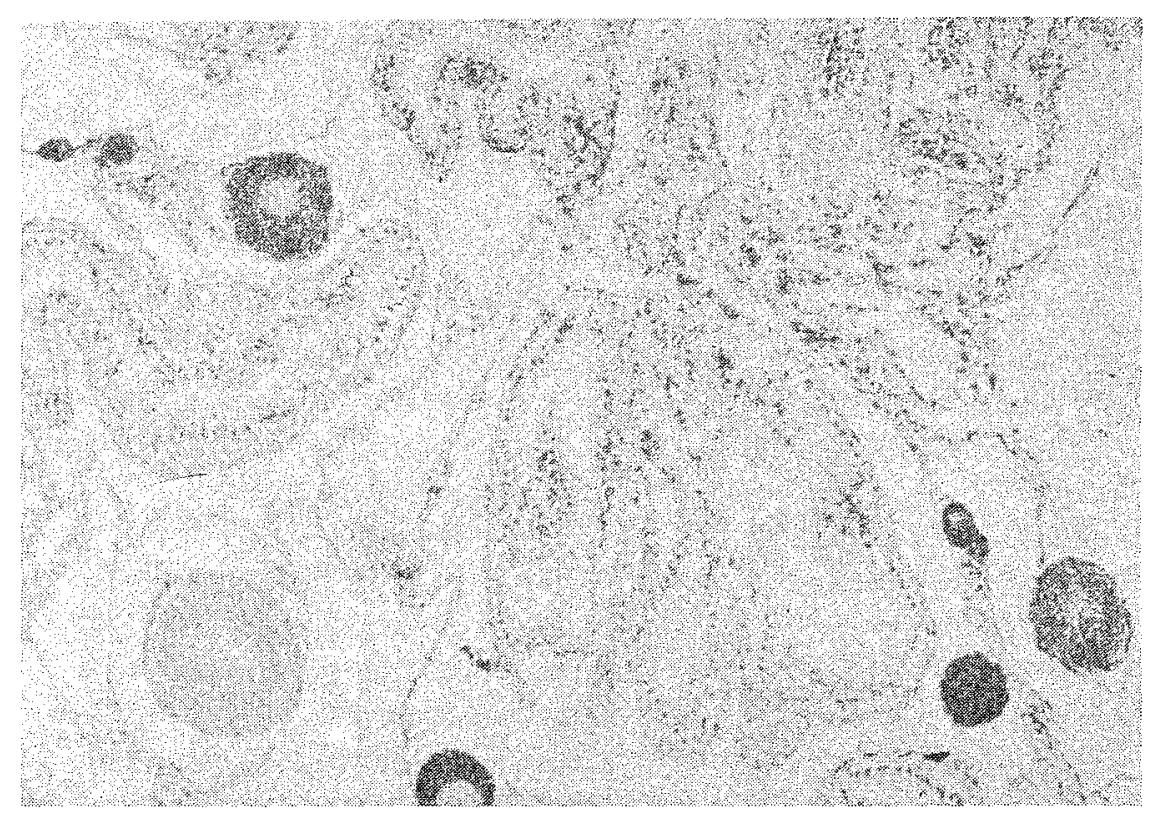

Fig. 3. December. Vendace ovary after spawning. Stage of development VI-III. Lake Isag. (magn. $120 \mathrm{x}$ ).

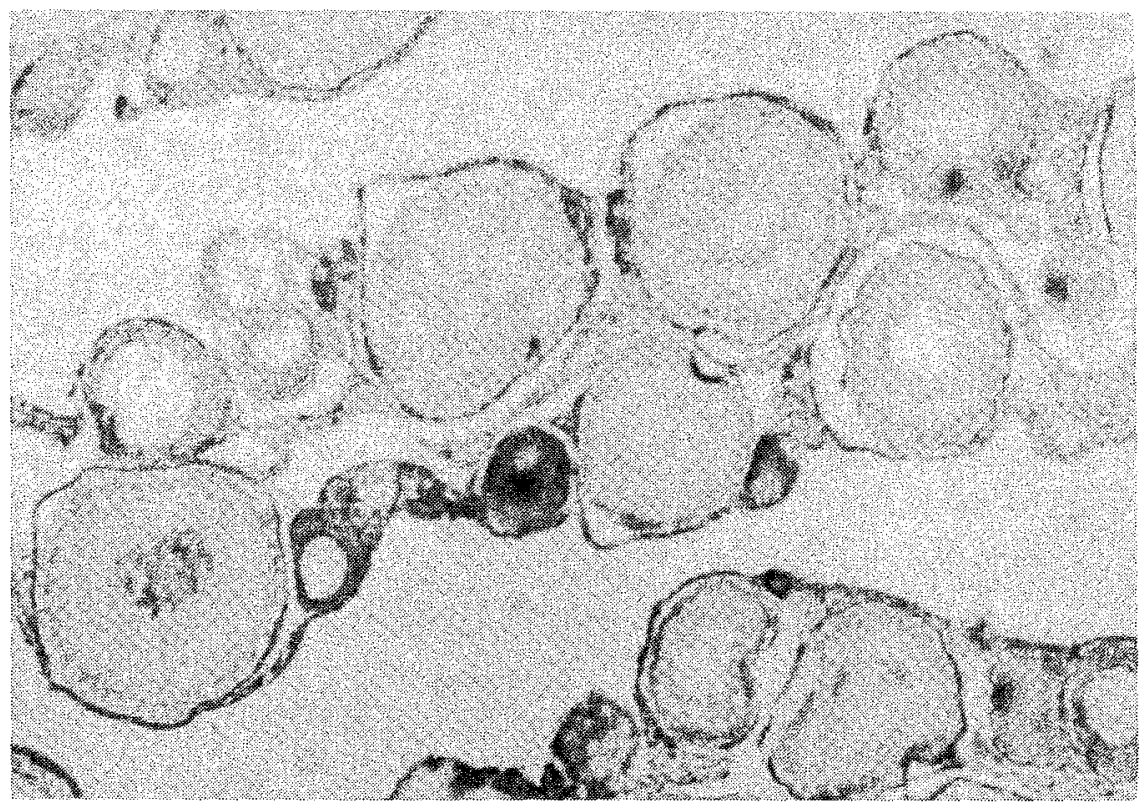

Fig. 4. March. III stage of the gonad. GSI $0.86 \%$. Lake Narie. (magn. $120 \mathrm{x}$ ) 


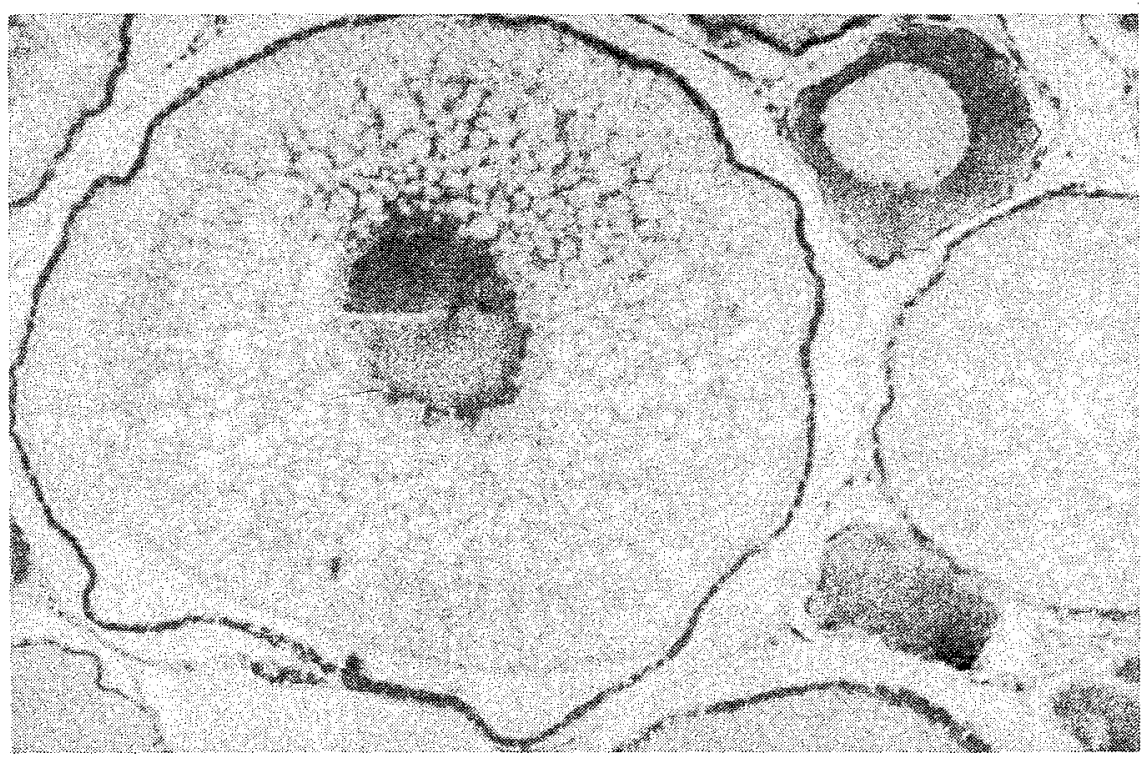

Fig. 5. June. Oocy tes in the III stage of development. GSI 1.16\%. Lake Isąg. (magn. $200 \mathrm{x}$ )

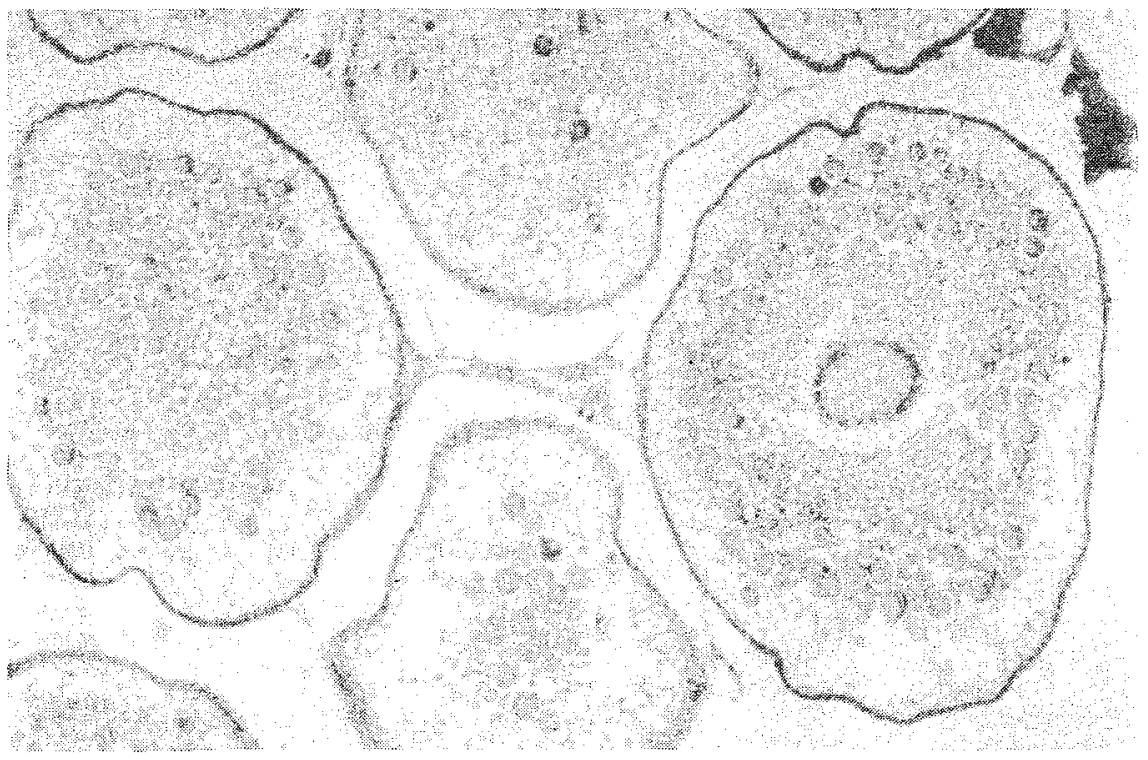

Fig. 6. July. Vendace ovary in stage IIIa. GSI 2.97\%. Lake Isąg. (magn. 120 x) 
Characteristics of vendace material from Lake Narie, with consideration given to body length (lc), body weight (w), index of maturity (GSI) and fish age

\begin{tabular}{|c|c|c|c|c|c|}
\hline $\begin{array}{c}\text { Month } \\
(1982 / 1983)\end{array}$ & Sex & $\mathrm{n}$ & $\begin{array}{c}\mathrm{lc} \\
(\mathrm{cm})\end{array}$ & $\begin{array}{l}W \\
(\mathrm{~g})\end{array}$ & age \\
\hline \multirow{2}{*}{ January } & $\delta$ & 3 & $19.0-19.5$ & $71.0-73.0$ & - \\
\hline & $q$ & 7 & $19.0-23.0$ & $65.0-110.0$ & - \\
\hline \multirow{2}{*}{ March } & 0 & 4 & $16.5-18.5$ & $47.0-60.5$ & - \\
\hline & $q$ & 6 & $15.5-18.5$ & $43.5-61.5$ & - \\
\hline \multirow{2}{*}{ June } & 0 & 5 & $18.0-20.0$ & $65.0-86.0$ & - \\
\hline & & 5 & $18.0-20.0$ & $65.0-114.0$ & - \\
\hline \multirow{2}{*}{ July } & $\delta$ & 3 & $17.4 \eta-19.0$ & $63.0-91.0$ & $2-3$ \\
\hline & $\bar{q}$ & 7 & $\overline{17.0-21.0}$ & $62.0-105.0$ & $2-3$ \\
\hline \multirow{2}{*}{ August } & $\delta$ & 5 & $17.0-18.5$ & $59.5-85.0$ & $2-3$ \\
\hline & $q$ & & $16.5-18.5$ & $57.0-86.0$ & 2 \\
\hline \multirow{2}{*}{ September } & 0 & 3 & $17.5-20.5$ & $66.0-103.0$ & $2-3$ \\
\hline & q & 7 & $17.0-20.5$ & $64.0-110.0$ & $\overline{2-3}$ \\
\hline \multirow{2}{*}{ October } & 0 & 6 & $14.5-18.5$ & $33.5-65.0$ & $1-2$ \\
\hline & 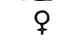 & 4 & $15.0-16.5$ & $37.0-55.5$ & $\overline{1-3}$ \\
\hline \multirow{2}{*}{ November } & 0 & - & - & - & - \\
\hline & q & 10 & $16.5-18.5$ & $50.2-83.0$ & $1-2$ \\
\hline \multirow{2}{*}{ December (3.XII) } & $0^{\pi}$ & 2 & $18.0-18.5$ & $68.0-72.0$ & - \\
\hline & $\bar{q}$ & $\overline{6}$ & $17.5-22.5$ & $\overline{55.0-145.0}$ & - \\
\hline \multirow{2}{*}{ December (9.XII) } & o & 2 & $18.0-18.5$ & $56.0-72.0$ & - \\
\hline & $q$ & 8 & $15.5-20.5$ & $50.0-96.0$ & - \\
\hline
\end{tabular}

In January and March all gonads were in the restinf stage (VI-III). This was confirmed by the index of maturity, which amounted to $0.26-0.86 \%$ (Tab. 2, 4). In January an increased number of the oocytes in stage III was observed in the histological picture.

Since December till March male gonads remained in the resting stage (VI). Most male gonads had empty ampules, noticeably separated by follicular epithelium (Fig. 9). Only in a few gonads spermatozoa were observed. At that time the gonado-somatic index ranged from 0.13 to $0.70 \%$ (Tab. 2, 4). In June and July spermatogonial divisions were observed in the ampules of some gonads. However, in some specimens lying spermatozoa were observed. At that time the GSI increased to 1.53\%. Since August and September spermatogenesis intensified. Gonado-somatic index increased and reached $3.88 \%$ in 


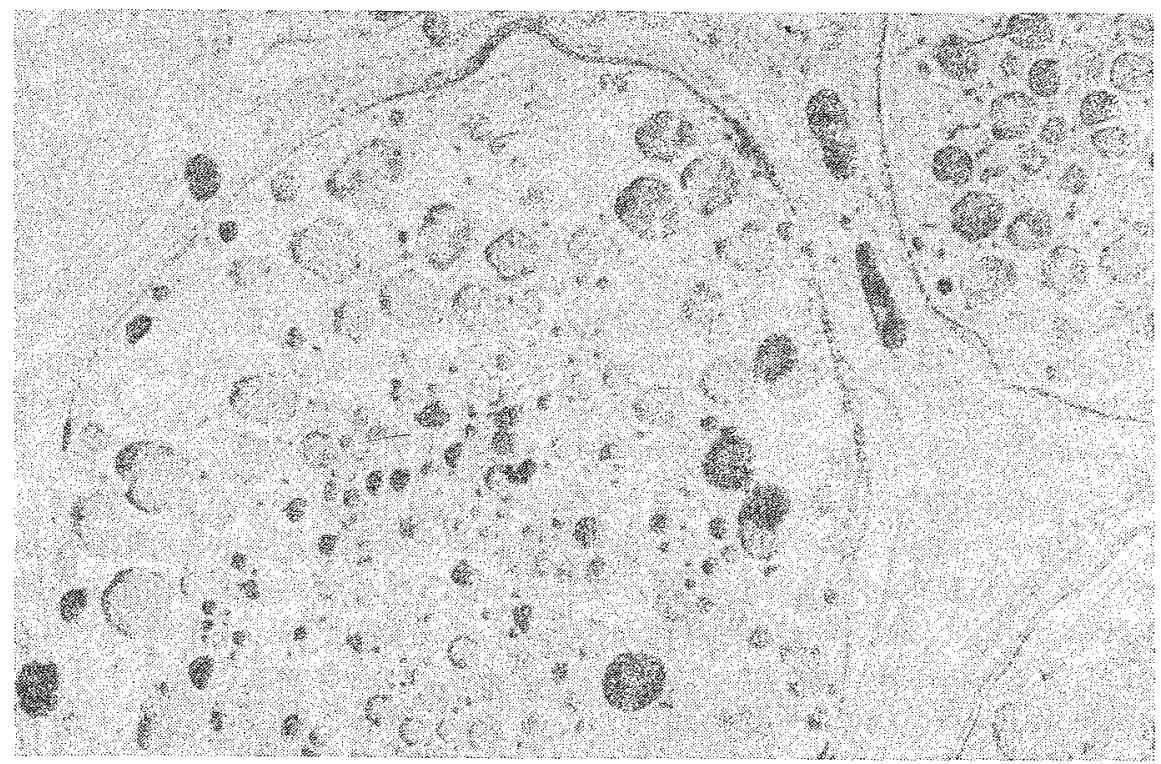

Fig. 7. September. III a stage of development. GSI 10.86\%. Atretic oocytes visible. Lake Isag. (magn. $120 \mathrm{x}$ ).

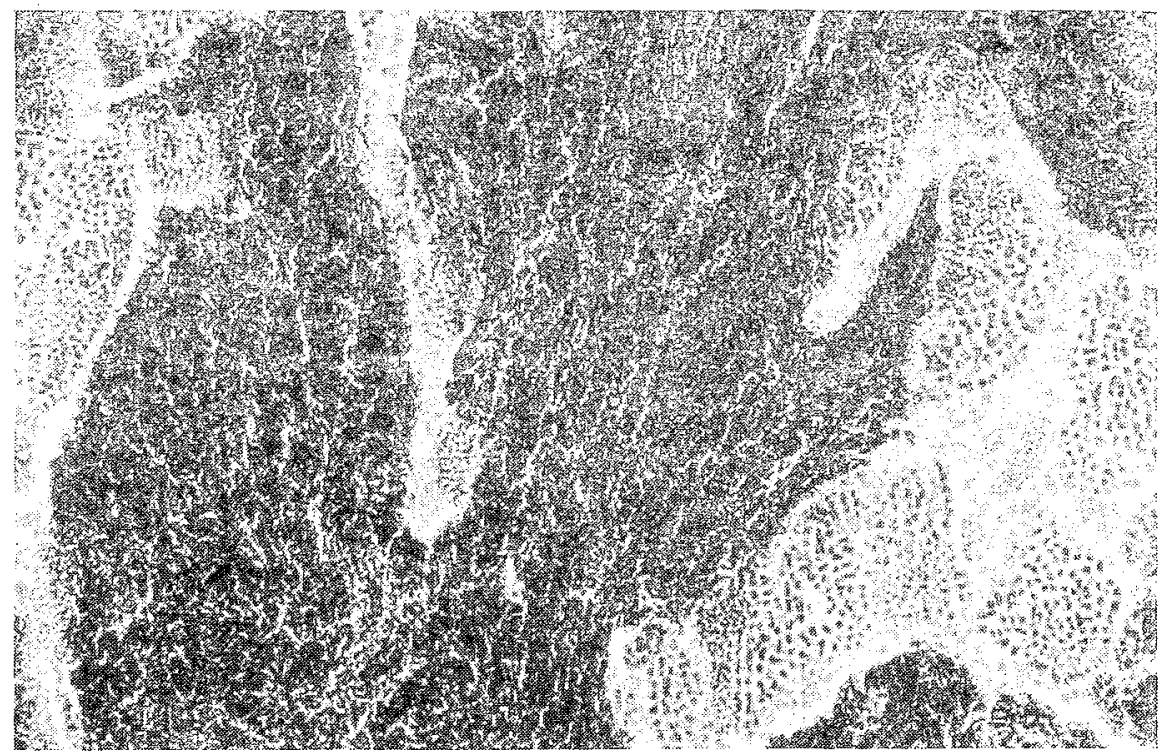

Fig. 8. October. Histological section of a male gonad. GSI 4.08\%. Lake Narie. (magn. $200 \mathrm{x}$ ). 
September. As regards the histological picture, ampule lights were filled with spermatozoids, and younger generations of germ cells were also noticeable in the cysts. In October value of the GSI amounted to $4.08 \%$. Ampule walls became very narrow, and mature spermatozoids constitued basic mass of the gonad (Fig. 8). In the first decade of November males were fully ready for spawning.

\section{Lake Isąg}

In June oocytes in the III stage of maturity were observed in the histological picture of the ovaries (Fig. 5). At that time the cells developed fairly homogenously, but their diameters were differentiated $(256.9-473.6 \mu \mathrm{m})$. The cytoplasm was totally vacuolized, and unilayer follicular and connective tissue membrane was noticeable around the oocyte circumference. Index of maturity varied between 0.09 and $1.16 \%$ (Tab. 3, 4).

Since July, process of accumulation of the nutritive substances commenced in the ovaries. Oocytes entered stage IIIa of maturity (Fig. 6). Zona radiata also became visible. Since July vendace ovaries contained germ cells in maturity stages IIIa, III and II. In all

Table 3

Characteristics of vendace material from Lake Isag, with consideration given to body length (lc), body weight (w), index of maturity (GSI) and fish age

\begin{tabular}{|c|c|c|c|c|c|}
\hline $\begin{array}{c}\text { Month } \\
(1982 / 1983)\end{array}$ & Sex & $\mathrm{n}$ & $\begin{array}{c}\mathrm{lc} \\
(\mathrm{cm})\end{array}$ & $\begin{array}{l}\text { W } \\
(\mathrm{g})\end{array}$ & age \\
\hline \multirow{2}{*}{ March } & ơ & 2 & $19.5-20.0$ & $23.0-23.5$ & $2-2$ \\
\hline & $q$ & $\overline{8}$ & $\overline{19.5-24.0}$ & $23.0-28.5$ & $2-5$ \\
\hline \multirow{2}{*}{ June } & 8 & 8 & $16.5-19.5$ & $59.0-95.5$ & - \\
\hline & $\bar{q}$ & 2 & $18.0-19.0$ & $82.0-86.0$ & - \\
\hline \multirow{2}{*}{ July } & o & 2 & $18.5-19.5$ & $73.0-87.0$ & 2 \\
\hline & $\bar{q}$ & 8 & $\overline{20.0-24.0}$ & $\overline{101.0-185.0}$ & $2-4$ \\
\hline \multirow{2}{*}{ August } & $\delta$ & 6 & $18.0-19.5$ & $62.0-97.0$ & $1-3$ \\
\hline & q & 4 & $20.0-21.5$ & $116.0-146.0$ & $2-3$ \\
\hline \multirow{2}{*}{ September } & ó & $\underline{2}$ & $19.0-20.0$ & $79.0-103.0$ & 2 \\
\hline & $q$ & 8 & $19.0-23.0$ & $90.0-152.0$ & $\overline{1-3}$ \\
\hline \multirow{2}{*}{ November } & $\underline{0}$ & $\underline{3}$ & $\underline{19.5-21.0}$ & $95.0-110.0$ & $2-3$ \\
\hline & q & 7 & $20.5-23.0$ & $\overline{102.0-161.0}$ & $1-3$ \\
\hline \multirow{2}{*}{ December } & 0 & $=$ & - & - & - \\
\hline & q & 2 & - & - & - \\
\hline
\end{tabular}




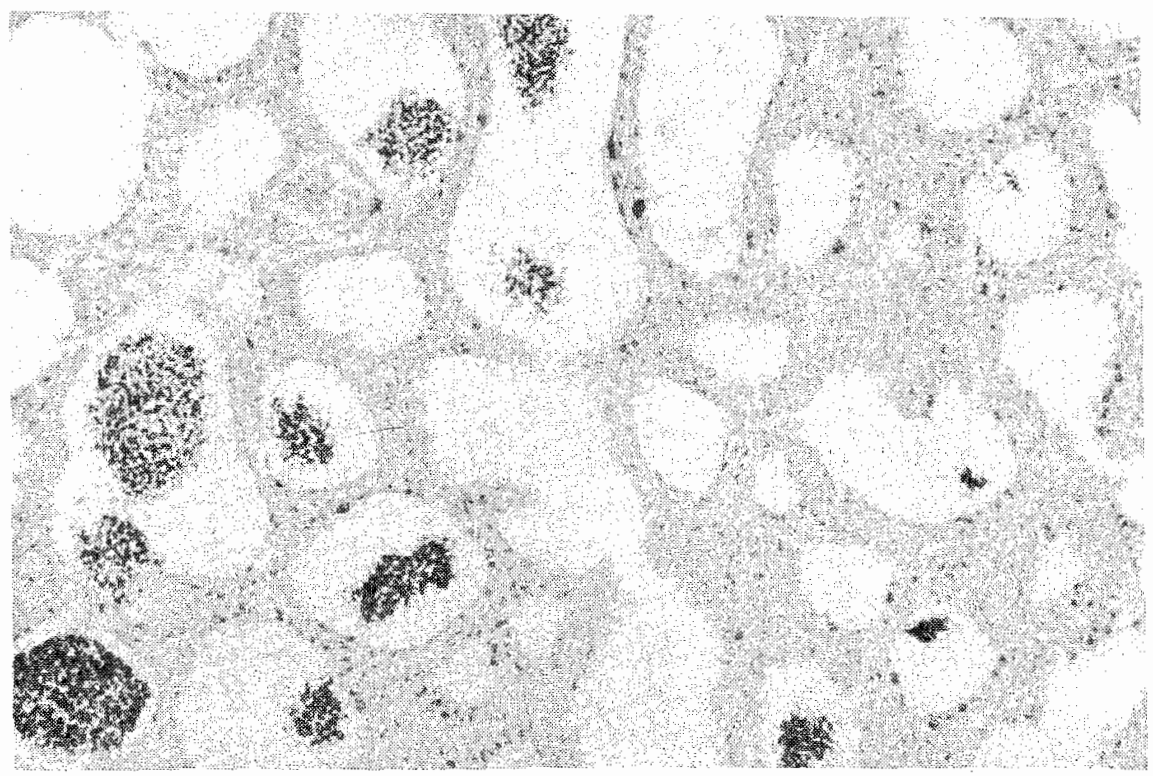

Fig. 9. December. Male gonad. VI stage of development. GSI 0.13\%. Empty ampules visible. Lake Narie. (magn. 200 x)

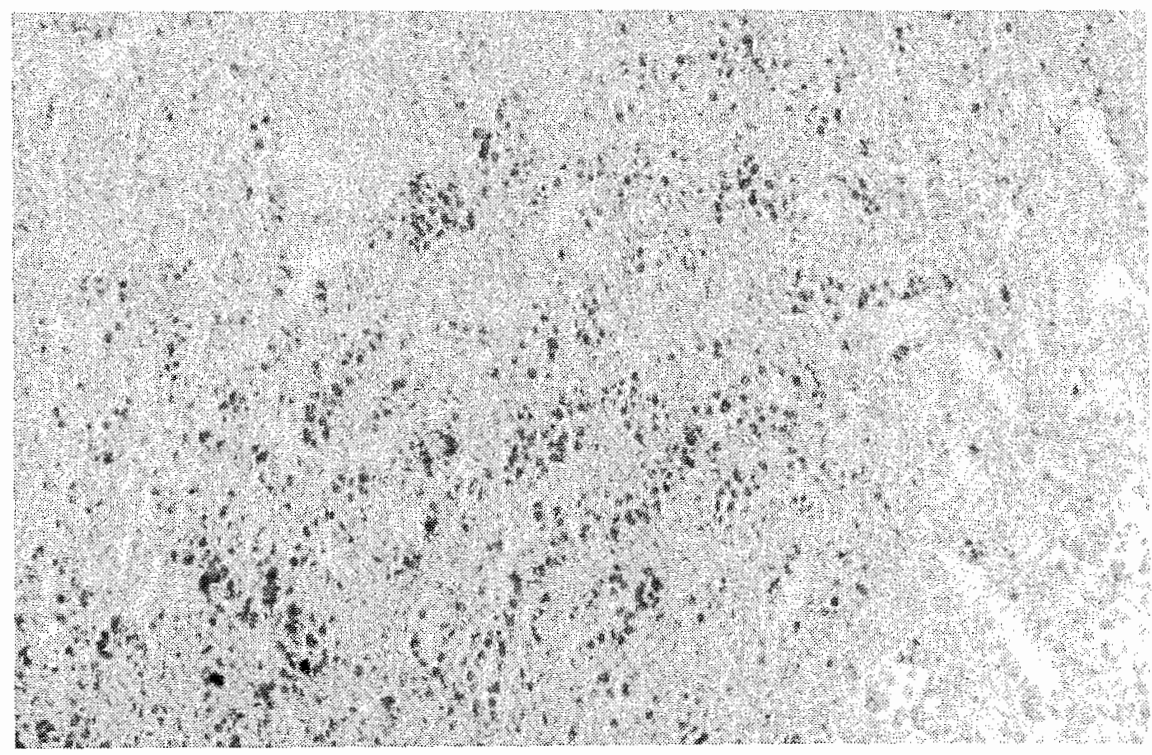

Fig. 10. March. Histological section of vendace testis. II stage of development. GSI $0.63 \%$. Lake Isąg. (magn. $200 \mathrm{x}$ ) 


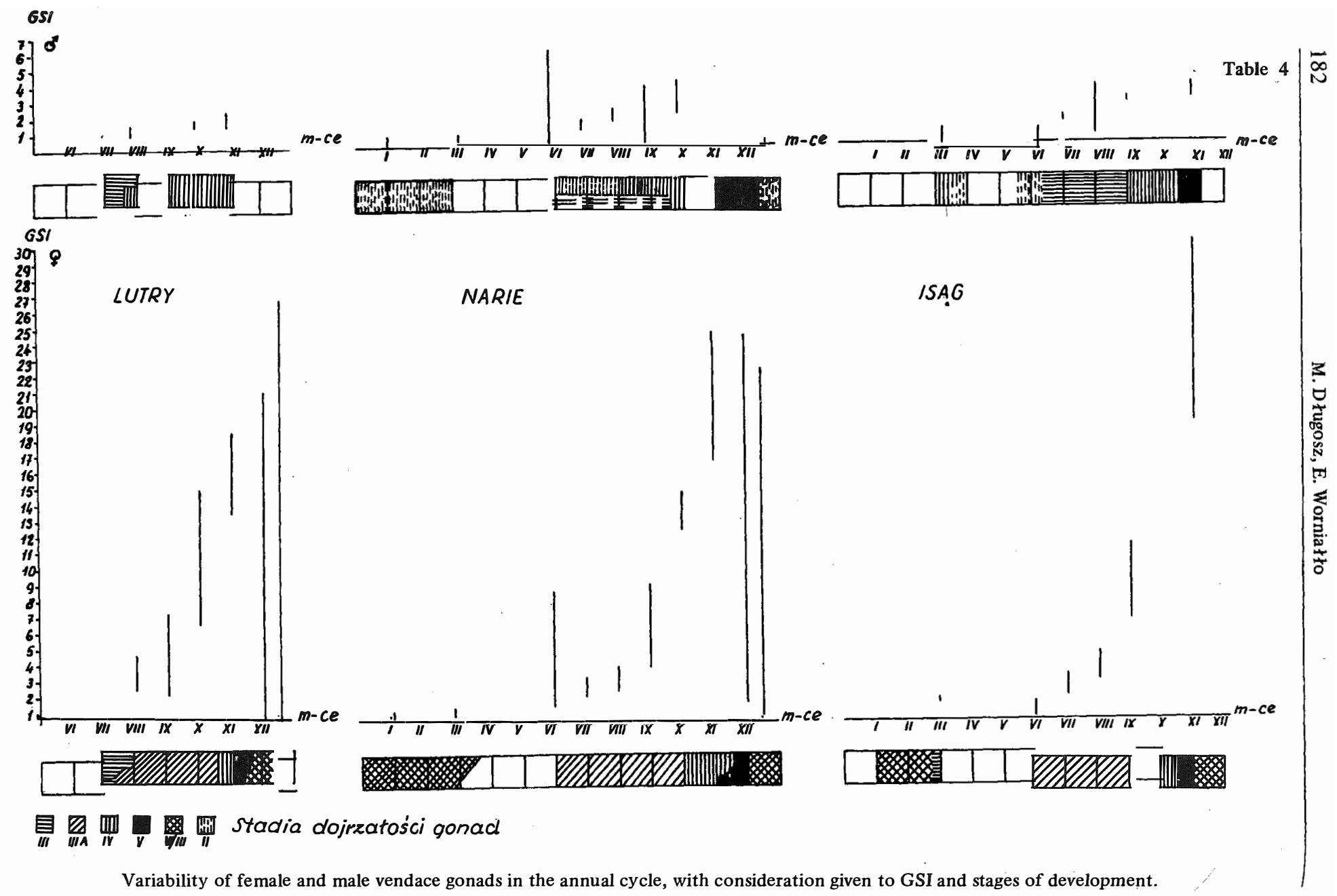


these stages diameter of the oocytes was considerably differentiated, amounting to $512-768 \mu \mathrm{m}$ for cells in the period of vitellogenesis, $371.2-512 \mu \mathrm{m}$ for cells in stage III, and $38.4-76.8 \mu \mathrm{m}$ for cells in stage II. This picture of the ovary persisted untill September. At that time diameter of germ cells increased due to the accumulation of nutritive substances. In September cells in stage IIIa had the diameter of 486.4-1113.6 $\mu \mathrm{m}$, stage III: $384-435.2 \mu \mathrm{m}$, and stage II: $64-166.4 \mu \mathrm{m}$ (Fig. 7).

Samples collected on 23 Nov. 1982 contained females ready for spawning. Only one female had the ovary with oocytes in the IV stage of maturity. The gonado-somatic index ranged between 18.51 and $29.92 \%$ (Tab. 3, 4).

In December the females were already spent. Ovaries were in stage VI-III. Empty follicular membranes were observed in the ovaries, as well as numerous oocytes in the II stage of maturity, and single cells with vacuolized cytoplasm (III stage of maturity). Ovaries collected in March 1983 contained numerous oocytes in stages $\mathbb{I}_{1,2}$ and III. Remnants of follicular membranes were still noticeable is some gonads, as well as single resorbed eggs. The gonado-somatic index amounted to $1.08-1.40 \%$ (Tab. 3, 4). Diameter of cells in the III stage of maturity ranged from 307.2 to $435 \mu \mathrm{m}$, and in the II stage from 64 to $179.2 \mu \mathrm{m}$. Cells of younger generation were very numerous.

In March in some male gonads the ampules were still filled with unshed spermatozoids, whereas other were already in the II stage of maturity (Fig. 10). GSI amounted to $0.63-1.17 \%$ (Tab. 4). In June unshed spermatozoids were still observed in some males, while new spermatogenesis commenced in the others, with the index of maturity amounting to $1.45 \%$ (Fig. 11). Spermiogenesis lasted since June till September (Fig. 12). Cells in different stages of development were observed in the ampule walls. By the end of August the ampule lights gradually filled with mature spermatozoids, and the gonads attained IV stage of maturity. The index of maturity reached 3.65\%. In the third decale of November all males were ready for spawning, and the gonado-somatic index varied between 2.85 and $3.63 \%$.

\section{DISCUSSION OF THE RESULTS}

Vendace differed in the lakes under study not only with respect to spawning period, but also as regards body size and weight (Tab. 1, 2, 3,4). The longest and the heaviest specimens were caught in Lake Isąg, while the smallest - in Lake Lutry (Tab. 1,4). Samples collected from vendace spawning populations usually contained fishes at the age of $1+$ to $2+$. Single specimens of older fishes $(4+, 5+)$ were caught in lakes Isąg and Narie (Tab. 2, 3). Vendace under study attained sexual maturity at the age of $1+$. The same was observed by Backiel (1952) in Lake Wigry. More to the north, in Lake Ladoga (Djatlov 1980) spawning population of vendace contained specimens at the age of $1+$ to $8+$, with the predomination of $3+$ to $5+$ age groups. The latter author stated that only in the third year of life $(2+)$ all individuals were sexually mature. 
Observations on the annual cycle of gonad development suggest that in the lakes under study vendace lied eggs in one portion only. This is confirmed by the following facts:

- prior to spawning all the oocytes were in the same stage of maturity, notwithstanding their different sizes;

- only cells in the II and early III stage of maturity were found in the ovaries after spawning.

Sakun and Buckaja (1968) proposed to define after-spawning stage in vendace as VI-III. Hence, II stage of maturity takes place only once in vendace life, i.e. when sexual maturity is attained for the first time.

Changes observed in vendace gonads in the annual cycle point to certain regularity, reflected in a succession of phases - stages of the germ cell development, both of quantitative (gonad weight) and qualitative (stages of development) character. It is known that these phases can be affected by a complex of environmental factors, abiotic and biotic ones. In case of fishes, the most important and noticeable ones are: temperature, day length, food resources etc. (Bieniarz and Opuszyński 1974, Ciepielewski 1974, Djatlov 1980, Sakun and Buckaja 1968, Kamler and Żuromska 1982, Dąbrowski 1983, Wootton and Evans 1876, Wootton 1979, Horoszewicz 1969, 1981, Morawska 1981). In the lakes under study commencement of spawning, as also duration of particular stages of sexual maturation, were slightly different.

The gonado-somatic index in course of the vitellogenesis and spermatogenesis increased continuously, reaching the highest values prior to spawning. In Lake Isąg the highest GSI of the ovary (29.9\%) was found in November, in Lakes Narie and Lutry - in mid-December (24.1 and $26.6 \%$ respectively) (Tab. 1, 2, 3, 4). In the two latter lakes some females had yet not spawned at that time. This was conformed by the histological picture of the gonads, but also by GSI index which ranged from 1.33 to $24.4 \%$ in Lake Narie, and from 0.25 to $22.7 \%$ in Lake Lutry (Tab. 1, 2, 4). Hence, in case of these two lakes, spawning was still taking place in mid-December. It should be underlined that in course of the vitellogenesis vendace from Lake Lutry possessed always oocytes in earlier stages of maturity than in other lakes. This phenomenon was most noticeable in November. In Lake Isąg the ovaries were in the V stage of maturity, in Lake Narie in the IV stage, while in Lake Lutry in stages IIIa and IV (Tab. 1, 2, 3, 4). After spawning all the females had the ovaries in stage VI-III. Resting period lasted untill March in Lake Isąg (about 3 months) (Fig. 3), and untill March in Lake Narie (about 2.5 months).

Usually the vacuolization process in fishes takes place in two ways. A ring of vacuole appears around the nucleus, or two rings are formed, one around the nucleus and the other close to cell walls. In case of vendace under study, vacuolization usually commenced in peripheral cell regions. The same was observed by Kuźmin (1975), and Sinjavixjus (1975). Nevertheless, formation of small vacuoli also around the nucleus was observed in some vendace oocytes. Similar phenomenon was noticed by Backiel (1952) in vendace from Lake Wigry.

In the lakes under study, the process of complete vacuolization, i.e. of slow growth, when the gonado-somatic index increased slowly, lasted from March till June in Lake 
Narie (Fig. 4), and till the end of June in Lake Isagg (Fig. 5, Tab. 2, 3,4). The gonado-somatic index increased rapidly in September in all lakes (Tab.4). Intensive vitellogenesis lasted untill November in Lake Isąg (Fig. 1), or untill the first and second decade of December in lakes Narie and Lutry (Fig. 2, Tab. 4). Untill this moment, single atretic eggs from previous spawning were noticed in the histological sections of the ovaries (Fig. 7).

Maturation stages IV and $\mathrm{V}$ are characterized in coregonid fishes by a dislocation of the nucleus toward the animal cell pole (Hosaja and Luczyński 1984), as well as by yolk fusion (Fig. 1,2). This process lasts for about 30 days, in this the $\mathrm{V}$ stage - only for a few days.

Hence, accumulation of trophic substances represents the longest period in the annual cycle of gonad development. It can last since June till December (Tab.4). In the lakes under study, the longest vitellogenesis (about 6.5 months) was observed in Lake Narie. In Lake Isąg it lasted for about 5 months, and in Lake Lutry for only 4 months. Sakun and Buckaja (1968) stated that long maturation was characteristic of autumn-spawning fishes, i.e. of salmonids and coregonids. In Lake Narie oocyte composition in the ovaries was very interesting in March. Vacuolized germ cells were observed, of the diameter of $192.9-307.2 \mu \mathrm{m}$, together with the oocytes in stage $\mathrm{II}_{1}$ with centrally located nucleus, of the size of $115.2-153.6 \mu \mathrm{m}$, as also the oocytes with dislocated nucleus, 38.4-89.6 $\mu \mathrm{m}$ in diameter (stage $\mathrm{II}_{2}$ ). In June the vacuolized cells passed to IIIa stage, and in December they attained full maturity and size of $1587.2 \mu \mathrm{m}$. On the other hand, oocytes which had been in stage II $_{1}$ entered a new phase of vacuolization in June (stage IIIa). Their diameters varied from 153.6 to $437.5 \mu \mathrm{m}$. These oocytes commenced vitellogenesis since July (IIIa, 230.4-601.6 $\mu \mathrm{m}$ ), but since September they were in the same stage of maturity as the previous cells. However, they were always smaller, and had wider zona radiata. In November diameter of these cells did not exceed $678.4 \mu \mathrm{m}$. The smallest cells, with nuclei located close to the cell wall, were most numerous in January - March and July August. It is possible that in vendace such supplementation with the oocytes takes place throughout the year, being most noticeable when the oocytes pass from one stage to another. Small oocytes in the previtellogenetic growth were observed throughout the year, but they were most numerous in the mentioned months. It can be assumed that these moments of oocyte supplementation depend on environmental factors, and might result in variable fecundity of vendace and different egg diameter in particular years. The same was observed for other fish species by Morawska (1981), Oven (1976) and others. It can be assumed that similar changes, although occurring in different periods, take place in female ovaries in other lakes. This problem will be delt with in future studies.

Changes in the male gonads of vendace are slightly different than in other fish species. Prolonged presence of spermatozoa in the ampules results in the fact that the GSI does not change throughout the year as much as in other species. In all lakes under study it was possible to distinguish four stages of cell maturation: resting, multiplication (II stage), slow and intensive spermiogenesis (stages III and IV), and spawning (V stage). However, particular phases did not take place at the same time in all individuals. Histological 


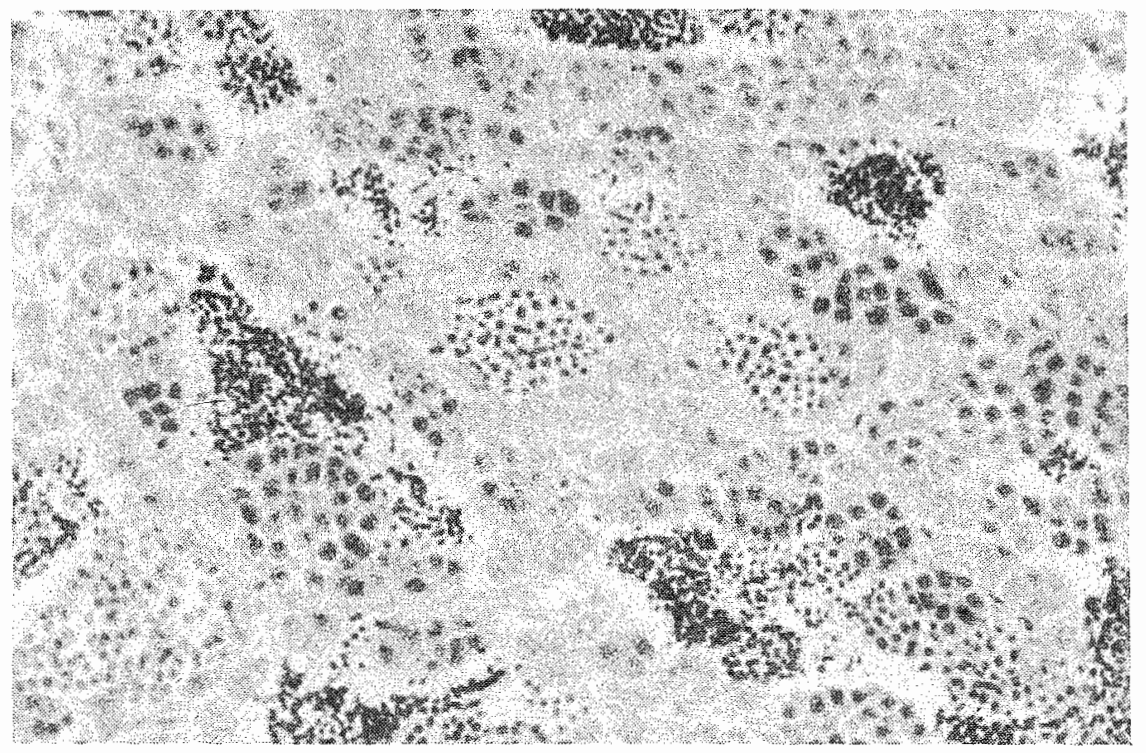

Fig. 11. June. Male gonad in the II/III stage of development. GSI 1.45\%. Lake Isag (magn. $400 \mathrm{x}$ )

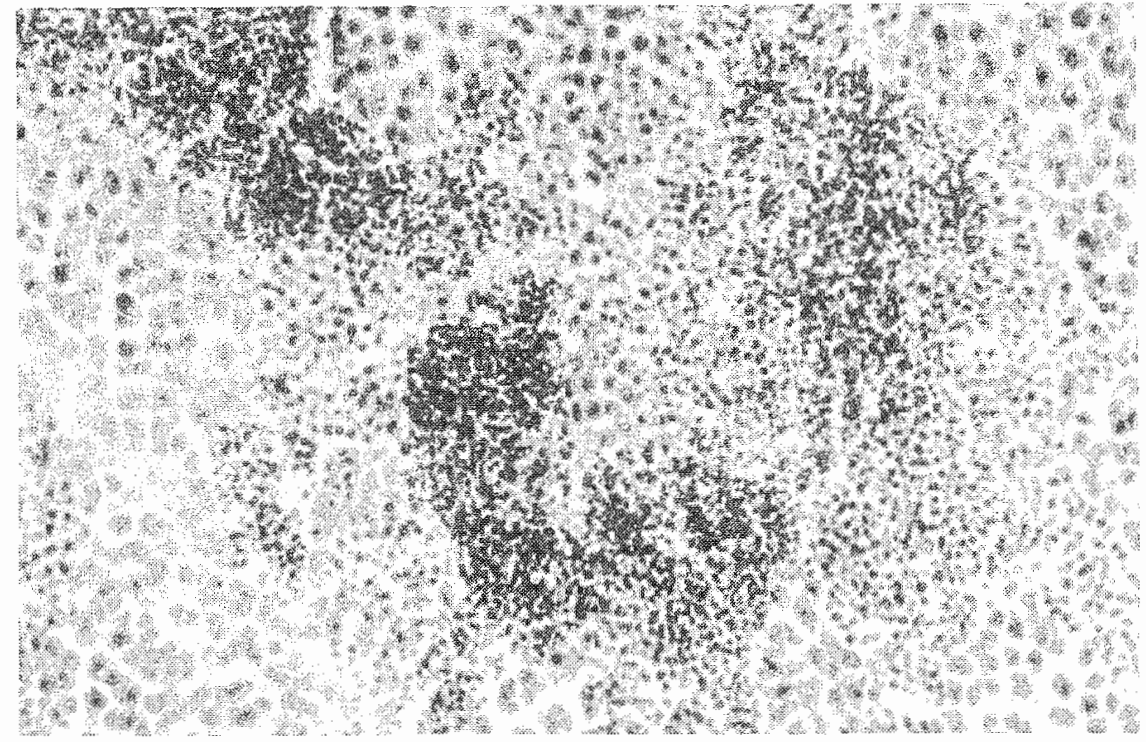

Fig. 12. August. Male gonad in the III stage of development. GSI $0.80 \%$. Lake Isag. 
structure of gonads in mature males was fairly differentiated since spawning till March. Some males had the gonads with gonial cells (Fig. 10), other had unshed spermatozoa in the ampules (Fig. 9). Unshed spermatozoa were observed for the longest time, untill June, in Lake Narie. However, since June, multiplication of the germ cells was observed in most males. Ampule walls became extended, and cells in different stages of development were observed in the cysts (Fig. 11). The GSI amounted to $1.45 \%$ in Lake Isąg, $1.53 \%$ in Lake Narie (Tab. 4). Since June till October in lakes Narie and Isąg (Fig. 12) and till December in Lake Lutry, stages III and IV of maturity were observed. In November and December the ampules became elongated and packed with spermatozoa (Fig. 8). In Lake Narie and Isąg males were ready for spawning in November, and in Lake Lutry - in December.

\section{SUMMARY OF THE RESULTS}

Changes of vendace gonads in the annual cycle in Mazurian lakes under study were as follows:

1. Spawning period was:

- in November in Lake Isąg,

- in December in Lakes Narie and Lutry,

2. Vacuolization process (stage III) was completed:

- by the end of June in Lake Isąg,

- at the begining of June in Lake Narie,

- no data for Lake Lutry.

3. Accumulation of fatty substances (stages IIIa, IV) lasted:

- since July till November in Lake Isąg,

- since June till December in Lake Narie,

- since the begining of August till December in Lake Lutry (no samples were collected in June and July).

4. Diameter of the oocytes in stage $\mathrm{V}$ - prior to spawning ranged:

- from 768.0 to $1420.8 \mu \mathrm{m}$ in Lake Isąg,

- from 678.4 to $1587.2 \mu \mathrm{m}$ in Lake Narie,

- from 1075.2 to $1600 \mu \mathrm{m}$ in Lake Lutry.

5. The least differentiated diameters were observed for vendace oocytes in Lake Lutry, the most - in Lake Narie.

6. Not all the oocytes passed into next stage of development at the same time. It can be assumed that this was the reason for considerable time span of spawning.

7. The highest values of the gonado-somatic index were found in Lake Isąg (29.9\%). In Lake Lutry it amounted to $26.6 \%$, and in Lake Narie to $24.1 \%$.

8. After spawning the ovaries passed into stage VI-III with no exceptions.

9. Individuals at the age of $1+$ were sexually mature and took part in spawning.

10. Vendace males were ready for spawning earlier than females.

11. In some male gonads unshed spermatozoa were observed as late as June (Lake Narie). 
12. Resumption of spermatogonial division (II stage of maturity - period of reconstruction) commenced in June in lakes Isąg and Narie, and in August in Lake Lutry.

13. In lakes Isąg and Narie an increase of the gonado-somatic index (period of spermiogenesis, III-IV stage of maturity) was observed since June till OctoberDecember. In Lake Lutry the same process was observed in males collected in August,

\section{REFERENCES}

Backiel T., 1952: Rozwój gruczołów płciowych sielawy (Coregonus albula L.) w cyklu rocznym. [Development of vendace (Coregonus albula L.) gonads in the annual cycle]. Rocz. Nauk Rol., 64: 271-295.

Bernatowicz St., 1963: Obserwacje nad rozwojem sielawy w kompleksie jezior Mamry. [Observations on vendace development in Mamry lake complex] - Rocz. Nauk Rol., 82-B2: 337-352.

Bieniarz K., Opuszyński K., 1974: Dojrzewanie płciowe ryb. (Synteza literatury światowej). [Sexual maturation in fishes. Synthesis of world literature]. Rocz. Nauk Rol., H-96, 3: 7-26.

Ciepielewski Wł., 1974: Obfitość składanych jaj i ocena przeżywalności narybku sielawy w jeziorze Maróz. [Abundance of shed eggs and estimation of vendace fry survival rate in Lake Maróz]. Rocz. Nauk Rol., H-96, 2: 23-36.

Dąbrowski K., 1983: Proces rozrodu ryb w aspekcie zmian chemicznych i biochemicznych ciała ze szczególnych uwzględnieniem ryb głąbielowatych. [The process of fish reproduction in the aspect of body chemical and biochemical changes, with special reference to coregonid fishes]. Zesz. Nauk. ART Olsžtyn, 12: 137-155.

Djatov M.A., 1980: K charakteristike nerestovogo stada rjapuski Coregonus albula L. Ladozskogo czera. - Vopr. Ichtiol. 20, 2: 350-354 (in Russian).

Horoszewicz L., 1969: Oddziaływanie podwyższonych temperatur na ryby. [Effects of increased temperature on fish] Ekol. pol., B-15, 4: 229-321.

Horoszewicz L., 1981: Effect of different thermal regimes on reproductive cycles of tench (tinca tinca L.). I. Design for the experiment and seasonal changes in conditions factors of spawners. Pol. Arch. Hydrobiol., 28: 2: 169-186.

Hosaja M., Zuczyński M., 1984: Micropyle of three coregoninae species (Teleostei). - Z. Angew. Zool 163 (in press).

Kamler E., Żuromska H., 1982: Bioenergetical evaluation of environmental and physiological factors determining egg quality and growth in Coregonus albula (L.). - Pol. Arch. Hydrobiol., 29, 1: $71-121$.

Kuźmin A.N., 1975: Nekotorye zakonomiernosti rozvitija vosproizvoditelnoj sistemy i periodizacija gametogeneza u sigowych. - Izv. Gos. Niorch. 104: 17-27 (in Russian).

Kužmin A.N., đubatova A.M., 1975: Razvitie polovych želez u samok nevskogo prochodnogo siga (Coregonus laveretus L.). Izv. GosNIORCH 104: 130-139 (in Russian).

Morawska B., 1981: Effect of different thermal regimes on reproductive cycles of tench (Tinca tinca L.). V. Method of estimation of fecundity. - Pol. Arch. Hydrobiol., 28, 2: 217-227.

Operat urządzeniowy jeziora Isąg, 1964: (Programme of management for Lake Isąg. - In manuscript Institute in Olsztyn). Maszynopis IRS - Olsztyn.

Operat urządzeniowy jeziora Lutry., 1965: (Programme of management for Lake Lutry. - In manuscript Institute in Olsztyn). Maszynopis IRS - Olsztyn.

Operat urządzeniowy jeziora Narie, 1968: (Programme of management for Lake Narie. - In manuscript Institute in Olsztyn). Maszynopis IRS - Olsztyn. 
Oven $\mathbb{L} . S_{.}, 1976$ : Osobennosti cogeneza i charakter neresta morskich ryb. - Kiev. Izdat. Naukova Dumka 131 (in Russian).

Sakun O.F., Buckaja N., 1968: Operedelenie stadija zrelosti i izučcenie polovych ciklov ryb. - Izd. Minist. Rybn. Choz. SSSR Murmansk. (in Russian).

Sinjaviçjus R.J., Sinjavicenije D.P., 1975: Razvitie vosproizvoditelnoj sistemy rjapuški ozera Dusja (Litovskaja SSR). - Izv. GosNIORCH 104: 140-151 (in Russian).

Wilkońska H., Żuromska H., 1981: Effect of environmental factors and egg quality on the morality of spawn in Coregonus albula (L.) and Coregonus lavaretus (L.) - Pol. Arch. Hydrobiol., 29, 1: 123-157.

Wootton R.J., Evans G.W., 1976: Cost of egg production in the three - spined sticleback (Gasterosteus aculeatus L.). - J. Fish. Biol., 8, 5: 385-395.

Wootton R.J., 1979: Energy cost of egg production and environmental determinations of facundity in Teleosts Fishes. - Symp. Zool. Soc. Lond., 44: 133-159.

Zawisza J., Backiel T., 1970: Gonad development, facundity and egg survival in Coregonus albula. Biology of Coregonid Fishes. Ed. by Lindsey C.C. and Woods C.S.: p. 363-397.

Żuromska H., 1982 a: Conditions of natural reproduction of Coregonus albula (L.). and Coregonus lavarentus (L.). - Pol. Arch. Hydrobiol., 29, 1: 1-28.

Zuromska H., 1982 b: Egg morality and its canses in Coregonus albula (L.). and Coregonus lavaretus (L.) in two masurian lakes. - Pol. Arch. Hydrobiol., 29, 1: 29-69.

Translated: Dr Teresa Bnińska

Mirosława Długosz, Ewa Worniłto

\author{
ZMIENNOŚĆ GONAD SIELAWY (COREGONUS ALBULA L.) \\ W CYKLU ROCZNYM Z TRZECH JEZIOR POJEZIERZA MAZURSKIEGO
}

\title{
STRESZCZENIE
}

Opracowanie, przedstawia wyniki obserwacji gonad sielawy (Coregonus albula L.) w cyklu rocznym z trzech jezior Pojezierza Mazurskiego; - Lutry, Isag i Narie. Jezior różniących się od siebie pod względem morfometrycznym. W wymienionych jeziorach poszczególne stadia rozwoju jajników przebiegały niejednakowo i wyrażały się zmienną długością czasu trwania. Ponadto w poszczególnych jeziorach w okresie odkładania substancji troficznych obserwowano niejednakowe średnice owocytów, a także nierównoczesne przechodzenie komórek płciowych w kolejne stadia dojrzałości. Tarło sielawy w Isagu odbywało się w listopadzie, natomiast w Narie i Lutrach w grudniu. Po rozrodzie w jajnikach obserwowano VI-III stadium dojrzałości. Do rozrodu przystępowały osobniki w wieku $1+$.

Gonady męskie gotowe były do tarła wcześniej niż żeńskie. U niektórych samców do czerwca obserwowano $\mathrm{w}$ ampułach zalegające plemniki. Wznowienie podziałów spermatogonialnych miało miejsce $w$ czerwcu w jeziorze Isag i Narie, natomiast w Lutrach dopiero w sierpniu. 
Mirosiawa Diugosz. Ewa Wornialio

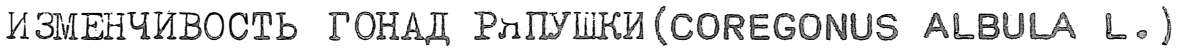 BUJOBJEHHOI B TPEX OЗЁPAX MAЗУPCKOГO ПОOЗЁРЬ, B ГОДОВОМ ЦИКJE}

$$
\text { P } 230 \text { M }
$$

В работе представлены результаты наблюдения нап гоналами ряпушщ (Coregonus albula Lo) в. Гопо вом цияле, выловленно й в трёх озёрах Мазурского

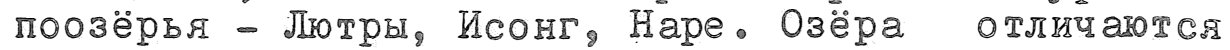
друг от друга своеи морфоме трие и. В выпеназван ных озёрах отдельные стадин развития яичников про-

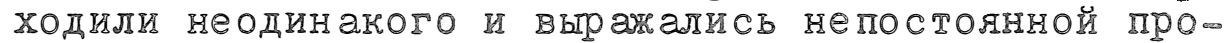

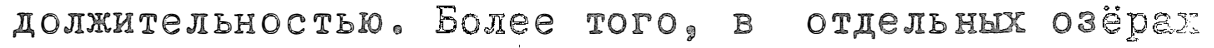

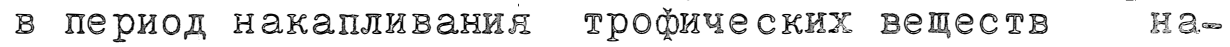
блюд али неодинаковые ди тетры овоцитов, а I неодновременныи пережод половых клетов в слептво щие стадии зрелости. Нерест ряпушки в оз. Исонг проходил в ноябре, а в оз. Наре и Jиотры - декабре. После размноненяя в яичниках ваблюдали VI

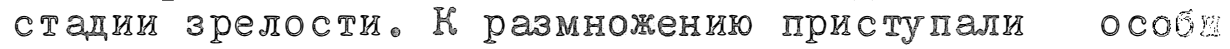
в возрасте 1t。

Mужские гонады были готовы в нересту ранвше, чем женские. у нежоторых самцов до йол наблидали в ампулах залегающие сперматозоиды. Обновление спея-

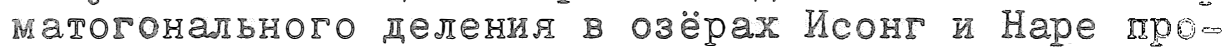

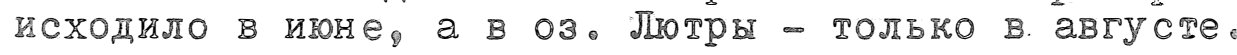

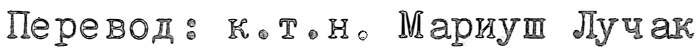

Author's address:

Dr Mirosława Długosz

Received: 84.08.10

Mgr Ewa Worniałło

Zakład Podstawowych Nauk Rybackich

10-957 Olsztyn - Kortowo

Polska (Poland) 